\title{
MENGEMBANGKAN KEMAMPUAN BERPIKIR KREATIF MATEMATIS MELALUI DISCOVERY LEARNING BERBASIS SCIENTIFIC APPROACH
}

\author{
Jayanti Putri Purwaningrum \\ Pendidikan Guru Sekolah Dasar, FKIP Universitas Muria Kudus \\ jayanti.putri@umk.ac.id
}

\begin{abstract}
Mathematical creative thinking ability is one of the capabilities that need to be owned and developed in students who study mathematics from primary to university level. This is due to those abilities in accordance with the vision of mathematics, national education goals and learning objectives of the school mathematics. This paper is a contribution of new ideas for implementing the curriculum in education so as to develop mathematical creative thinking ability in school. Information about mathematical creative thinking ability derived based on a literature review. The study results are expected that mathematical creative thinking ability can progress through discovery learning based scientific approach.
\end{abstract}

Keywords: Mathematical Creative Thinking Ability, Discovery Learning Based Scientific Approach.

\begin{abstract}
ABSTRAK
Kemampuan berpikir kreatif matematis adalah salah satu kemampuan yang perlu dimiliki dan dikembangkan pada siswa yang belajar matematika dari tingkat SD sampai tingkat perguruan tinggi. Hal ini disebabkan kemampuan-kemampuan tersebut sesuai dengan visi matematika, tujuan pendidikan nasional, dan tujuan pembelajaran matematika sekolah. Makalah ini merupakan sumbangan pemikiran baru bagi pelaksana kurikulum di dunia pendidikan agar mengembangkan kemampuan berpikir kreatif matematis di sekolah. Informasi tentang kemampuan berpikir kreatif matematis diperoleh berdasarkan kajian literatur. Hasil kajian diharapkan bahwa kemampuan berpikir kreatif matematis siswa dapat berkembang melalui discovery learning berbasis scientific approach.
\end{abstract}

Kata kunci: Kemampuan Berpikir Kreatif Matematis, Discovery Learning Berbasis Scientific Approach

\section{PENDAHULUAN}

Tujuan pendidikan yang diselenggarakan pada setiap satuan pendidikan mengacu pada Undang-Undang No 20 Tahun 2003 yaitu mengembangkan siswa agar menjadi manusia yang beriman dan bertakwa kepada Tuhan
Yang Maha Esa, berakhlak mulia, sehat, berilmu, cakap, kreatif, mandiri dan menjadi warga negara yang demokratis serta bertanggung jawab. Salah satu cara untuk mencapai tujuan pendidikan tersebut adalah dengan dimuatnya matematika sebagai mata 
pelajaran wajib bagi siswa dari tingkat SD sampai tingkat perguruan tinggi.

Pada Permendiknas Nomor 22 tahun 2006 tentang Standar Kompetensi dan Kompetensi Dasar Kurikulum 2006, disebutkan bahwa matematika perlu diberikan kepada semua siswa mulai dari sekolah dasar untuk membekali siswa dengan kemampuan berpikir logis, analitis, sistematis, kritis, dan kreatif serta kemampuan bekerjasama. Kompetensi tersebut diperlukan agar siswa dapat memiliki kemampuan memperoleh, mengelola, dan memanfaatkan informasi untuk bertahan hidup pada keadaan yang selalu berubah, tidak pasti, dan kompetitif. Salah satu tujuan pembelajaran matematika dalam Kurikulum 2006 adalah mengembangkan aktivitas kreatif yang melibatkan imajinasi, intuisi dan penemuan, dengan mengembangkan pemikiran divergen, orisinal, rasa ingin tahu, membuat prediksi dan dugaan serta mencobacoba. Kurikulum tersebut juga menyebutkan bahwa salah satu prinsip kegiatan belajar mengajar adalah mengembangkan kreativitas siswa. Dengan demikian, kurikulum KTSP 2006 mengisyaratkan bahwa pentingnya mengembangkan kreativitas dalam pembelajaran matematika.

Pentingnya pengembangan kreativitas pada matematika juga terdapat pada Kurikulum 2013. Hal ini terbukti dengan adanya Peraturan Pemerintah Nomor 17 Tahun 2010 dalam Kurikulum 2013 tentang Pengelolaan dan Penyelenggaraan Pendidikan, yang menyebutkan bahwa tujuan penyelenggaraan pendidikan dasar dan menengah yaitu membangun landasan bagi berkembangnya potensi siswa agar menjadi manusia yang berilmu, cakap, kritis, kreatif, dan inovatif. Kurikulum tersebut juga menyebutkan bahwa salah satu kriteria mengenai kualifikasi kemampuan lulusan yang harus dimiliki oleh siswa yaitu memiliki kemampuan berpikir kreatif dalam ranah abstrak dan konkret sesuai dengan yang dipelajari di sekolah dan sumber lain yang sejenis. Pada matematika, kemampuan berpikir kreatif matematis merupakan produk dari kreativitas matematika sedangkan aktivitas kreatif merupakan kegiatan dalam pembelajaran yang diarahkan untuk mendorong atau memunculkan kreativitas siswa. Walaupun dalam Kurikulum KTSP 2006 maupun Kurikulum 2013, kemampuan berpikir kreatif matematis merupakan kemampuan yang harus dikuasai siswa, akan tetapi pada kenyataannya pengembangan kemampuan tersebut belum optimal.

Studi yang dilakukan oleh Risnanosanti (2009) menyebutkan bahwa pada kelas XI salah satu Sekolah Menengah Atas (SMA) di kota Bengkulu, siswa kurang mampu dalam menyelesaikan soal-soal pada salah satu indikator kemampuan berpikir kreatif matematis, yakni kebaruan. Hal ini disebabkan mereka tidak terbiasa menyelesaikan permasalahan dengan caranya sendiri. Selain itu, berkaitan dengan pembelajaran matematika di kelas XI tersebut, terungkap bahwa siswa belum terbiasa dalam memecahkan soal matematika yang bersifat terbuka. Penelitian kualitatif Purwaningrum (2012) pada siswa kelas XI salah satu SMA di Kabupaten Pekalongan yang membagi siswa menjadi tiga kelompok yaitu kelompok siswa kreatif, kurang kreatif dan tidak kreatif, menunjukkan bahwa pada pembelajaran pengajuan masalah, siswa pada kategori kurang kreatif dan tidak kreatif mengalami kesulitan pada indikator fleksibilitas dan kebaruan. Siswa pada kelompok kategori tersebut membutuhkan waktu yang lama untuk memunculkan ide. Ketika menemukan ide, mereka juga tidak yakin terhadap ide soal pengajuan masalah sekaligus penyelesaian masalahnya.

Kurang optimalnya pengembangan kemampuan berpikir kreatif matematis juga dapat dilihat dari penelitian Huda (2014) di kelas VIII salah satu SMP di Kota Bandung, yang menunjukkan bahwa berdasarkan hasil uji perbedaan rata-rata data skor posttest,

\section{Jurnal Refleksi Edukatika}

Vol. 6 No. 2 Juni 2016 
kemampuan berpikir kreatif matematis siswa yang memperoleh pembelajaran open-ended dengan setting kooperatif lebih baik daripada siswa yang memperoleh pembelajaran konvensional. Artinya, perlakuan yang diberikan terhadap kedua kelas memberikan kontribusi terhadap kemampuan berpikir kreatif matematisnya. Akan tetapi hasil yang dicapai siswa belum maksimal sehingga masih perlu ditingkatkan. Hal tersebut dikarenakan siswa belum terbiasa mengembangkan kemampuan berpikir kreatif matematisnya, yang diperkuat dengan adanya keluhan siswa pada saat diminta memunculkan berbagai alternatif jawaban.Huda (2014) menjelaskan lebih lanjut bahwa hasil tes kemampuan berpikir kreatif matematis yang diperoleh siswa belum maksimal sebab tidak semua siswa di kelas membuka diri dengan pendekatan yang dilakukan. Terkadang siswa malas untuk berpikir, mencari ide lain atau solusi alternatif dari masalah yang diberikan. Penyebab lainnya yaitu siswa terbiasa dengan soal rutin dan tidak dibiasakan untuk mencari sendiri penyelesaian masalah dengan cara yang berbeda dengan temannya.

Berdasarkan data penelitian yang telah disebutkan, dapat diketahui bahwa penyebab mengapa kreativitas dalam pembelajaran matematika tidak dapat berkembang secara optimal karena seseorang terlalu dibiasakan untuk berpikir secara prosedural sehingga terhalang kemungkinannya untuk merespon dan memecahkan persoalan secara bebas. Orang yang berpikir secara prosedural semacam ini terbiasa mengikuti pola bersikap dan berperilaku sebagaimana pola yang dikembangkan oleh lingkungannya. Hal ini sebagaimana dikemukakan oleh Sugilar (2012) bahwa kemampuan berpikir kreatif matematis siswa tidak dapat berkembang dengan baik apabila dalam proses kegiatan belajar mengajar, metode pembelajaran yang digunakan di sekolah masih berpusat pada guru yang tidak melibatkan siswa secara aktif dalam pembentukan konsep. Sumarmo (2005) menyarankan pembelajaran matematika yang mendorong berpikir kreatif dan berpikir tingkat tinggi antara lain dapat dilakukan melalui belajar dalam kelompok kecil, menyajikan tugas non rutin, dan tugas yang menuntut strategi kognitif dan metakognitif siswa. Pembelajaran dalam matematika yang memenuhi kiteria tersebut antara lain yaitu discovery learning berbasis scientific approach.

Bruner (Kemendikbud, 2014) mendefinisikan discovery learning sebagai suatu situasi dimana materi yang diajarkan tidak dalam bentuk final atau sudah jadi tetapi diperlukan kegiatan mental siswa lebih dulu sehingga membentuk pengetahuan baru dalam struktur kognitif siswa. Discovery learning berbasis scientific approach diartikan sebagai pembelajaran dalam kelompok kecil yang membimbing siswa untuk menemukan suatu konsep dengan menggunakan pendekatan ilmiah, melalui beberapa tahapan, yaitu: (1) Stimulasi atau pemberian rangsangan; (2) Identifikasi atau pernyataan masalah; (3) Pengumpulan data; (4) Pengolahan data; (5) Pembuktian; dan (6) Generalisasi atau menarik kesimpulan.

Berdasarkan latar belakang di atas, adapun rumusan masalah yang perlu dikaji yaitu bagaimanakah cara untuk mengembangkan kemampuan berpikir kreatif siswa melalui discovery learning berbasis scientific approach? Sedangkan tujuan dari penulisan makalah ini yaitu menggali informasi berdasarkan kajian literatur tentang cara untuk mengembangkan kemampuan berpikir kreatif siswa melalui discovery learning berbasis scientific approach.

\section{Kajian Pustaka dan Pembahasan \\ 1.1 Berpikir}

Mahmud (2010) menyatakan bahwa dalam tataran praktik, berpikir memiliki tiga definisi yaitu: (1) Berpikir adalah mengotakatik rumus; (2) Berpikir adalah mendefinisikan objek konkret menjadi abstrak 
melalui visualisasi; dan (3) Berpikir adalah menarik kesimpulan dari realitas yang dipahami. Di sisi lain, Suryadi (2005) menyatakan bahwa berpikir berkaitan erat dengan apa yang terjadi di dalam otak manusia dan fakta-fakta yang ada dalam dunia sehingga bisa divisualisasikan dan berpikir (manakala diekspresikan) bisa diobservasi dan dikomunikasikan.

Pada umumnya, berpikir diasumsikan sebagai proses kognitif yaitu suatu aktivitas mental yang lebih menekankan penalaran untuk memperoleh pengetahuan (Presseisen dalam Somakim, 2010). Ruggiero (Siswono, 2008) mengartikan berpikir sebagai suatu aktivitas mental untuk membantu memformulasikan atau memecahkan suatu masalah, membuat suatu keputusan, atau memenuhi hasrat keingintahuan. Pendapat ini menunjukkan bahwa ketika seseorang merumuskan suatu masalah, memecahkan masalah, ataupun ingin memahami sesuatu maka ia melakukan suatu aktivitas berpikir.

Kaitannya dengan pendidikan matematika, Sumarmo (2006) secara umum mengartikan berpikir matematik sebagai pelaksanaan kegiatan atau proses matematika (doing math) atau tugas matematika (mathematical task). Ditinjau dari kedalaman atau kegiatan matematik, kegiatan berpikir dalam matematika dibagi menjadi dua, yaitu berpikir matematik tingkat rendah (low order mathematical thinking) dan berpikir matematik tingkat tinggi (high order mathematical thinking).

Pada proses pembelajaran, proses terjadinya berpikir merupakan faktor yang paling penting. Piaget (Suryadi, 2005) mengemukakan tiga faktor dalam pembelajaran berpikir, yaitu (1) Perlunya memperhatikan mengapa seorang anak berpikir dengan cara tertentu; (2) Perlu diingat bahwa berpikir adalah berbuat sehingga merupakan suatu proses yang aktif; dan (3) Perlu bagi anak untuk melakukan eksplorasi tentang konsep-konsep kunci tertentu yang dapat mengungkapkan potensi yang mereka miliki.

\subsection{Kreativitas}

Definisi kreativitas menurut Seltzer dan Bentley (Craft, 2001) adalah penerapan pengetahuan dan keterampilan dalam caracara baru untuk mencapai tujuan yang diharapkan. Untuk mencapai hal tersebut, siswa harus memiliki empat hal yaitu: (1) Kemampuan untuk mengidentifikasi masalah baru, bukan tergantung pada orang lain untuk mendefinisikannya; (2) Kemampuan untuk mentransfer pengetahuan yang didapat dalam satu konteks yang lain dalam rangka untuk memecahkan masalah; (3) Sebuah keyakinan dalam belajar sebagai suatu proses mental, dimana akan meningkatkan keberhasilan; dan (4) Kemampuan untuk memusatkan perhatian dalam mengejar tujuan. Selanjutnya, Munandar (1999) mendefinisikan kreativitas menggunakan pendekatan atau strategi empat $P$, yaitu sebagai berikut.

a. Pribadi, kreativitas adalah ungkapan dari keunikan individu ketika berinteraksi dengan lingkungannya. Dari ungkapan pribadi yang unik inilah diharapkan timbul berbagai ide-ide baru dan produkproduk yang inovatif.

b. Pendorong, menekankan pada kondisi internal (dorongan yang berasal lingkungan) yang dapat mendorong seseorang untuk mengembangkan kreativitasnya. Dengan demikian, untuk mewujudkan bakat kreatif siswa maka diperlukan dorongan dan dukungan dari lingkungan (motivasi eksternal) yang berupa apresiasi, dukungan, pemberian penghargaan, pujian, dan lain-lain.

c. Proses, kreativitas adalah kesempatan untuk bersibuk diri secara kreatif. Pendidik hendaknya dapat merangsang anak untuk melibatkan dirinya dalam berbagai kegiatan kreatif. Dalam hal ini yang penting adalah memberikan

\section{Jurnal Refleksi Edukatika}

Vol. 6 No. 2 Juni 2016 
kebebasan kepada anak untuk mengapresiasikan dirinya secara kreatif.

d. Produk, kondisi yang memungkinkan seseorang untuk menciptakan produk kreatif bermakna yang berasal dari kondisi pribadi dan lingkungannya. Kondisi tersebut melibatkan seseorang dalam proses kreatif.

Krutetskii (Siswono, 2008) menjelaskan bahwa kemampuan kreatif sekolah berhubungan pada suatu penguasaan kreatif mandiri (independent) matematika di bawah pengajaran matematika, formulasi mandiri masalah-masalah matematis yang tidak rumit (uncomplicated), penemuan cara-cara dan sarana dari penyelesaian masalah, penemuan bukti-bukti teorema, pendeduksian mandiri rumus-rumus dan penemuan metode-metode asli penyelesaian masalah non standar. Semua itu tidak diragukan lagi adalah suatu manivestasi dari kreativitas matematis. Penjelasan Kruteskii menunjukkan bahwa kreativitas matematika sekolah merupakan bagian dari kreativitas matematika yang meliputi formulasi masalah matematis, pemecahan masalah, penemuan bukti-bukti teorema, atau deduksi struktur matematis. Kreativitas matematika sekolah tersebut dapat berupa formulasi (pengajuan) masalah matematis yang tidak rumit, penemuan caracara penyelesaian suatu masalah, pembuktian teorema, atau penurunan rumus-rumus.

\subsection{Kemampuan Berpikir Kreatif Matematis}

Berpikir kreatif merupakan suatu kebiasaan dari pikiran yang dilatih dengan memperhatikan intuisi, menghidupkan imajinasi, mengungkapkan kemungkinankemungkinan baru, membuat sudut pandang yang menakjubkan dan membangkitkan ideide yang tidak terduga (Usman, 2014). Selanjutnya, LTSIN (2004) mendefinisikan secara khusus berpikir kreatif adalah proses untuk menghasilkan ide baru dan ide baru tesebut merupakan ide-ide gabungan yang sebelumnya belum digabung-gabungkan. Pendapat Usman dan LTISN tersebut sejalan dengan Evans (Siswono, 2008) yang menyatakan bahwa berpikir kreatif adalah suatu aktivitas mental untuk membuat hubungan-hubungan (connections) yang terus menerus sehingga ditemukan kombinasi yang "benar" sampai orang menyerah. Asosiasi kreatif terjadi melalui kemiripan-kemiripan sesuatu atau melalui kemiripan analogis. Asosiasi ide-ide tersebut kemudian membentuk ide baru. Dari pendapat Usman, LTISN dan Evans, dapat ditarik kesimpulan bahwa berpikir kreatif mengabaikan hubungan-hubungan yang sudah ada untuk kemudian menciptakan hubungan-hubungan tersendiri. Pendapat-pendapat tersebut menunjukkan bahwa berpikir kreatif merupakan kegiatan mental untuk menemukan suatu kombinasi yang belum pernah ada sebelumnya.

Munandar (1999) mengindikasikan kemampuan berpikir kreatif adalah kemampuan menemukan banyak kemungkinan jawaban terhadap suatu masalah, dimana penekanannya pada kuantitas, ketepatgunaan, dan keberagaman jawaban. Pendapat tersebut menunjukkan bahwa kemampuan berpikir kreatif seseorang makin tinggi, jika ia mampu menunjukkan banyak kemungkinan jawaban pada suatu masalah. Semua jawaban itu harus sesuai, tepat, dan bervariasi. Lebih lanjut, Munandar (1999) menjelaskan bahwa ciri-ciri kemampuan berpikir kreatif sebagai berikut.

a. Fluency (keterampilan berpikir lancar) yaitu keterampilan berpikir lancar memiliki ciri-ciri yaitu mencetuskan banyak pendapat, jawaban, penyelesaian masalah, memberikan banyak cara atau saran dalam melakukan berbagai hal, dan selalu memikirkan lebih dari satu jawaban.

b. Flexibility (keterampilan berpikir luwes) yaitu keterampilan menghasilkan gagasan, 
jawaban, atau pertanyaan yang bervariasi, dapat melihat suatu masalah dari sudut pandang yang berbeda-beda, mencari banyak alternatif pemecahan yang berbeda-beda dan mampu mengubah cara pendekatan.

c. Originality (keterampilan berpikir orisinil) yaitu kemampuan melahirkan gagasan baru dan unik, memikirkan cara yang tidak lazim untuk mengungkapkan diri, dan mampu membuat kombinasi yang tidak lazim.

d. Elaboration (keterampilan memperinci) yaitu kemampuan memperkaya dan mengembangkan suatu gagasan atau produk, dan menambahkan atau memperinci secara detil dari suatu situasi sehingga lebih menarik.

Kemampuan berpikir kreatif dalam matematika mengacu pada pengertian kemampuan berpikir kreatif secara umum. Krulik dan Rudnick (Siswono, 2007) menjelaskan bahwa berpikir kreatif merupakan pemikiran yang bersifat asli, reflektif, dan menghasilkan suatu produk yang kompleks. Kemampuan berpikir tersebut melibatkan sintesis ide-ide, membangun ideide baru dan menentukan efektivitasnya. Selain itu, juga melibatkan kemampuan untuk membuat keputusan dan menghasilkan produk yang baru. Pengertian ini tidak menyebutkan bahwa berpikir kreatif hanya bersifat intuitif yang lepas dari berpikir logis, dan tidak pula menyebutkan dengan tegas bahwa berpikir kreatif sebagai sintesis atau kombinasi dari berpikir logis dan berpikir divergen yang intuitif. Pendapat Krulik dan Rudnick lebih melihat berpikir kreatif sebagai satu kesatuan yang di dalamnya terdapat proses berpikir logis maupun divergen yang saling menunjang dan tidak terpisahkan.

\subsection{Discovery Learning Berbasis Scientific Approach}

Sund (Suryosubroto, 2009) berpendapat bahwa discovery adalah proses mental dimana siswa mengasimilasi suatu konsep atau suatu prinsip. Proses mental tersebut, misalnya mengamati, menggolong-golongkan, membuat dugaan, menjelaskan, mengukur, membuat kesimpulan, dan sebagainya. Yang dimaksud konsep, misalnya segitiga, demokrasim panas, energi, dan sebagainya, sedangkan prinsip, misalnya logam apabila dipanaskan akan mengembang, lingkungan berpengaruh terhadap organisme, dan sebagainya. Menurut Kemendibud (2014), discovery learning lebih menekankan pada ditemukannya konsep atau prinsip yang sebelumnya tidak diketahui dan pada discovery, masalah yang diajukan kepada siswa merupakan masalah yang direkayasa oleh guru.

Bruner (Arends, 2008) menjelaskan bahwa discovery learning adalah sebuah model pengajaran yang menekankan pentingnya membantu siswa untuk memahami struktur atau ide-ide kunci suatu disiplin ilmu, kebutuhan akan keterlibatan aktif siswa dalam proses belajar, dan keyakinan bahwa pembelajaran sejati terjadi melalui personal discovery (penemuan pribadi). Kemendikbud (2014) menambahkan bahwa prinsip belajar yang nampak jelas dalam discovery learning adalah materi atau bahan ajar yang akan disampaikan tidak disampaikan dalam bentuk final tetapi siswa didorong untuk mengidentifikasi apa yang ingin diketahui, kemudian dilanjutkan dengan mencari informasi sendiri dengan melakukan berbagai kegiatan menghimpun informasi, membandingkan, mengkategorikan, menganalisis, mengintegrasikan, mengorganisasi atau membentuk (konstruktif) apa yang mereka ketahui dan mereka pahami dalam suatu bentuk akhir (membuat kesimpulan).

Pernyataan Kemendibud sejalan dengan pendapat Herdian (2010), yang mengemukakan bahwa dalam pembelajaran discovery, siswa dibiarkan menemukan sendiri atau mengalami proses mental sendiri, guru hanya membimbing dan memberikan intruksi. 
Penggunaan discovery learning, pada dasarnya ingin mengubah kondisi belajar yang pasif menjadi aktif dan kreatif. Mengubah pembelajaran yang teacher oriented ke student oriented. Mengubah modus pembelajaran ekspositori dimana siswa hanya menerima informasi secara keseluruhan dari guru ke modus pembelajaran discovery dimana siswa menemukan informasi sendiri (Kemendikbud, 2014). Hal itu sama halnya dengan pernyataan Schuman (Suryosubroto, 2009) yang menyatakan proses pengajaran discovery melibatkan murid dalam proses kegiatan mental melalui tukar pendapat berwujud diskusi, seminar, dan sebagainya. Artinya, proses pengajaran berpindah dari situasi teacher dominated learning ke situasi student dominated learning.

Syah (Kemendikbud, 2014) menjelaskan bahwa terdapat beberapa prosedur yang harus dilaksanakan dalam mengaplikasikan discovery learning yaitu: (1) ) Stimulasi atau pemberian rangsangan; (2) Identifikasi atau pernyataan masalah; (3) Pengumpulan data; (4) Pengolahan data; (5) Pembuktian; dan (6) Generalisasi atau menarik kesimpulan.

Scientific approach atau lebih dikenal dengan nama pendekatan saintifik merupakan pendekatam atau proses kerja yang memenuhi kriteria ilmiah. Pendekatan ini lebih mengedepankan pelararan induktif (inductive reasoning) dibandingkan dengan penalaran deduktif (deductivereasoning). Penalaran induktif merupakan penalaran yang memandang fenomena atau situasi spesifik untuk kemudian menarik simpulan secara keseluruhan sedangkan penalaran deduktif melihat fenomena umum untuk kemudian menarik simpulan yang spesifik. Metode ilmiah mengacu pada teknik-teknik investigasi atas suatu atau beberapa fenomena atau gejala, memperoleh pengetahuan baru, atau mengoreksi dan memadukan pengetahuan sebelumnya. Untuk dapat disebut ilmiah, metode pencarian (method of inquiry) harus berbasis pada bukti-bukti dari objek yang dapat diobservasi, empiris, dan terukur dengan prinsip-prinsip penalaran yang spesifik.Karena itu, metode ilmiah umumnya memuat serangkaian aktivitas pengumpulan data melalui observasi atau ekperimen, mengolah informasi atau data, menganalisis, kemudian memformulasi, dan menguji hipotesis. Proses pembelajaran

Dari paparan di atas, dapat disimpulkan bahwa discovery learning berbasis scientific approach diartikan sebagai pembelajaran dalam kelompok kecil yang membimbing siswa untuk menemukan suatu konsep dengan menggunakan pendekatan ilmiah, melalui beberapa tahapan, yaitu: (1) Stimulasi atau pemberian rangsangan; (2) Identifikasi atau pernyataan masalah; (3) Pengumpulan data; (4) Pengolahan data; (5) Pembuktian; dan (6) Generalisasi atau menarik kesimpulan. Pendekatan ilmiah yang dilakukan meliputi:
(2) Menanya;
(3)

(1) Mengamati;

Mengumpulkan informasi; (4) Mengasosiasi; dan (5) Mengkomunikasikan.

\subsection{Keterkaitan antara Kemampuan Berpikir Kreatif Matematis dengan Discovery Learning Berbasis Scientific Approach}

Matematika merupakan salah satu mata pelajaran inti baik dalam Kurikulum KTSP 2006 maupun Kurikulum 2013 yang diberikan mulai dari pendidikan dasar. Pada matematika, pengembangan kemampuan siswa tidak hanya untuk menghasilkan lulusan yang mempunyai pengetahuan kognitif yang luas tetapi juga memiliki keterampilam, kemampuan, sikap dan nilai untuk melanjutkan pendidikan, tanggap terhadap perkembangan IPTEK dan seni serta memecahkan masalah yang dihadapinya untuk hidup di masyarakat. Oleh karena itu, agar sasaran tersebut dapat tercapai maka penekanan pada proses pembelajaran tidak hanya pada apa yang harus dipelajari (learning what to be learn) tetapi belajar bagaimana belajar (learning how to learn). Konsep 
tersebut bertumpu pada empat pilar pembelajaran, yaitu (1) learning to know (belajar mengetahui); (2) learning to do (belajar berbuat); (3) learning to be (belajar mejadi dirinya); dan (4) learning to live together (belajar menjadi dirinya).

Dewasa ini, telah terjadi pergeseran paradigma pendidikan, yang semula paradigma pendidikan berorientasi masukan ke pendekatan yang berorientasi pada standar yang terdiri dari standar kompetensi lulusan, standar isi, standar proses dan standar penilaian. Dengan kata lain, bergeser dari pertanyaan "kompetensi apa saja yang harus diajarkan kepada siswa" ke pertanyaan "kompetensi apa yang harus dikuasai oleh siswa". Hal ini dapat diilustrasikan bahwa melalui pendekatan ini, guru tidak lagi memberi "umpan" kepada siswa untuk akan tetapi "kail" supaya siswa dapat mencari "umpan" sendiri. Oleh karena itu, pendekatan pembelajaran yang tepat untuk mencapai berbagai kompetensi tersebut harus menyentuh tiga ranah, yang meliputi (1) ranah keterampilan (transformasi substansi atau materi ajar agar peserta didik "tahu bagaimana"); (2) ranah pengetahuan (transformasi substansi atau materi ajar agar peserta didik "tahu apa"); dan (3) ranah sikap (transformasi substansi atau materi ajar agar peserta didik "tahu mengapa"). Dengan demikian, hasil akhir dari pengoptimalan ketiga ranah tersebut adalah peningkatan dan keseimbangan antara kemampuan untuk menjadi manusia yang baik (soft skills) dan manusia yang memiliki kecakapan (hard skills) dari peserta didik yang meliputi aspek kompetensi sikap, keterampilan, dan pengetahuan.

Baik pada Kurikulum 2006 maupun Kurikulum 2013 terdapat tiga komponen pokok yang harus dikembangkan dan berorientasi pada karakteristik kompetensi keterampilan, pengetahuan, dan sikap. Salah satu pembelajaran yang akhir-akhir ini banyak digunakan di sekolah-sekolah adalah model penemuan dengan menggunakan pendekatan saintifik (discovery learning berbasis scientific approach) yang karakteristik kompetensinya disesuaikan dengan jenjang pendidikan. Kemdikbud (2014) menyatakan bahwa pendekatan saintifik yang diterapkan pada mata pelajaran matematika merupakan pendekatan yang memenuhi kriteria ilmiah. Untuk dapat disebut ilmiah, metode pencarian (method of inquiry) harus berbasis pada buktibukti dari objek yang dapat diobservasi, empiris, dan terukur dengan prinsip-prinsip penalaran yang spesifik. Hal ini mengakibatkan pada metode ilmiah umumnya memuat serangkaian aktivitas pengumpulan data melalui ekperimen atau observasi, mengolah informasi atau data, menganalisis, kemudian memformulasi, dan menguji hipotesis. Dengan demikian, pada setiap kegiatan belajar mengajar matematika, guru harus memberikan kesempatan kepada siswa untuk mengkonstruksi pengetahuan dalam proses kognitifnya. Kegiatan pembelajaran yang dilakukan pun lebih menekankan pada pengalaman langsung untuk mengembangkan kompetensi agar siswa mampu memahami alam sekitar melalui "mencari tahu" dan "berbuat" sehingga membantu siswa untuk memperoleh pemahaman yang lebih mendalam. Penguasaan berbagai konsep matematika memungkinkan siswa untuk mengembangkan berbagai kemampuan dalam menjelaskan berbagai peristiwa alam yang dialami maupun yang dibaca dengan gagasannya sendiri, diantaranya adalah kemampuan berpikir kreatif matematis. Berdasarkan uraian di atas, proses pembelajaran matematika tidak hanya sekadar memperoleh hasil (product) dalam bentuk "jawaban yang benar". Namun, juga diperlukan kemampuan berpikir kreatif matematis dalam diri siswa untuk mengungkapkan kemampuannya dalam berbagai cara.

Pada umumnya, setiap orang mengetahui pengertian dari kemampuan berpikir kreatif

\section{Jurnal Refleksi Edukatika}


dan betapa pentingnya kemampuan tersebut dalam segala aspek kehidupan. Hal ini terlihat dari bagaimana orang selalu membicarakan agar anak memiliki kemampuan berpikir kreatif, bahkan pengembangan kemampuan tersebut tidak hanya dalam dunia pendidikan tetapi juga pada setiap aspek, baik seni tari, seni lukis, memasak, mendesain, perkembangan ilmu pengetahuan, maupun teknologi. Pertanyaannya? Bagaimana menghasilkan siswa yang memiliki kemampuan berpikir kreatif?

Mariati (2006) menjelaskan bahwa siswa yang kreatif dapat dihasilkan dengan melibatkan mereka untuk aktif dalam pembelajaran. Hingga saat ini keterlibatan siswa dalam pembelajaran belum optimal. Hal ini sebabkan oleh pembelajaran yang mengarah pada teacher centered. Selain itu, pembelajaran yang dilakukan lebih didominasi oleh pertanyaan atau tugas-tugas dalam bentuk pertanyaan tertutup baik dalam proses maupun dalam hasil. Hal ini mengakibatkan siswa sudah terpola dan diarahkan untuk memilih satu jawaban yang benar sehingga potensi siswa tidak dapat digali dan dikembangkan. Hal ini sejalan dengan pemikiran Munandar (2009), yang menyebutkan bahwa perkembangan optimal dari kemampuan berpikir kreatif berhubungan erat dengan cara mengajar. Kemampuan berpikir kreatif anak akan berkembang atas prakarsanya sendiri bila suasana pembelajaran tidak otoriter dan anak diberi kesempatan untuk bekerja sesuai dengan minat serta kebutuhannya. Hal ini dikarenakan guru menaruh kepercayaan terhadap kemampuan anak untuk berpikir dan berani mengemukakan gagasan baru. Pada mata pelajaran matematika, pembelajaran yang dapat mengembangkan kemampuan berpikir kreatif matematis diantaranya adalah discovery learning berbasis scientific approach.

Menurut Bruner (Kemendikbud, 2014), tujuan utama discovery learning adalah guru memberikan kesempatan kepada siswa untuk menjadi seorang problem solver, seorang scientist, historin, atau ahli matematika sehingga melalui kegiatan tersebut, mereka akan menguasai, menerapkan, serta menemukan hal-hal yang bermanfaat bagi dirinya. Lebih lanjut, Bruner (Mustafa, 2014) mengidentifikasi enam indikator dalam discovery learning yang memunculkan perkembangan kognitif, yaitu: (1) Menanggapi situasi dalam berbagai cara daripada selalu dengan cara yang sama; (2) Internalisasi peristiwa ke dalam "sistem penyimpanan" yang sesuai dengan ligkungan; (3) Meningkatkan kapasitas bahasa; (4) Interaksi sistematis dengan tutor (orangtua, guru, atau contoh tauladan lain); (5) Bahasa sebagai sebuah instrumen untuk memerintahkan lingkungan; dan (6) Meningkatkan kapasitas untuk berhadapan dengan lebih dari satu permintaan. Sedangkan komponen yang ada pada discovery learning yaitu: (1) Rasa ingin tahu dan ketidakpastian; (2) Struktur pengetahuan; (3) Pengurutan; dan (5) Motivasi (Thorsett dalam Mustafa, 2014).

Terdapat beberapa prosedur yang harus dilaksanakan dalam mengaplikasikan discovery learning yaitu sebagai berikut.

a. Stimulation (stimulasi atau pemberian rangsangan).

Pada tahap ini, siswa dihadapkan pada sesuatu yang menimbulkan kebingungan, kemudian dilanjutkan untuk tidak memberi generalisasi, agar timbul keinginan untuk menyelidiki sendiri. Disamping itu, guru dapat memulai kegiatan dengan mengajukan pertanyaan, anjuran membaca buku, dan aktivitas belajar lainnya yang mengarah pada persiapan pemecahan masalah. Stimulasi pada tahap ini berfungsi untuk menyediakan kondisi interaksi belajar yang dapat mengembangkan dan membantu siswa dalam mengeksplorasi bahan. Pada hal ini, Bruner memberikan stimulasi dengan menggunakan teknik bertanya yaitu dengan mengajukan pertanyaan-pertanyaan yang dapat menghadapkan siswa pada kondisi internal 
yang mendorong eksplorasi. Dengan demikian, seorang guru harus menguasai teknik-teknik dalam memberi stimulus kepada siswa agar tujuan mengaktifkan siswa untuk mengeksplorasi dapat tercapai.

b. Problem statement (pernyataan atau identifikasi masalah)

Setelah dilakukan stimulasi, langkah selanjutnya adalah guru memberi kesempatan kepada siswa untuk mengidentifikasi sebanyak mungkin agenda-agenda masalah yang relevan dengan bahan pelajaran. Kemudian, salah satunya dipilih dan dirumuskan dalam bentuk hipotesis (jawaban sementara atas pertanyaan masalah). Sedangkan menurut permasalahan yang dipilih itu selanjutnya harus dirumuskan dalam bentuk pertanyaan, atau hipotesis, yakni pernyataan (statement) sebagai jawaban sementara atas pertanyaan yang diajukan. Memberikan kesempatan siswa untuk mengidentifikasi dan menganalisa permasalahan yang mereka hadapi, merupakan teknik yang berguna dalam membangun siswa agar mereka terbiasa untuk menemukan suatu masalah.

c. Data collection (pengumpulan data)

Ketika eksplorasi berlangsung, guru juga memberi kesempatan kepada para siswa untuk mengumpulkan informasi sebanyakbanyaknya yang relevan untuk membuktikan benar atau tidaknya hipotesis. Pada tahap ini berfungsi untuk menjawab pertanyaan atau membuktikan benar tidaknya hipotesis. Dengan demikian, anak didik diberi kesempatan untuk mengumpulkan (collection) berbagai informasi yang relevan, membaca literatur, mengamati objek, wawancara dengan narasumber, melakukan uji coba sendiri dan sebagainya. Konsekuensi dari tahap ini adalah siswa belajar secara aktif untuk menemukan sesuatu yang berhubungan dengan permasalahan yang dihadapi sehingga secara tidak disengaja siswa menghubungkan masalah dengan pengetahuan yang telah dimiliki. d. Data processing (pengolahan data)

Pengolahan data merupakan kegiatan mengolah data dan informasi yang telah diperoleh siswa baik melalui wawancara, observasi, dan sebagainya. Semua informasi hasil bacaan, wawancara, observasi, dan sebagainya, semuanya diolah, diacak, diklasifikasikan, ditabulasi, bahkan bila perlu dihitung dengan cara tertentu serta ditafsirkan pada tingkat kepercayaan tertentu. Data processing disebut juga dengan pengkodean atau coding kategorisasi yang berfungsi sebagai pembentukan konsep dan generalisasi. Dari generalisasi tersebut, diharapkan siswa akan mendapatkan pengetahuan baru tentang alternatif jawaban atau penyelesaian yang perlu mendapat pembuktian secara logis.

e. Verification (pembuktian)

Pada tahap ini, siswa melakukan pemeriksaan secara cermat untuk membuktikan benar atau tidaknya hipotesis yang ditetapkan tadi dengan temuan alternatif kemudian dihubungkan dengan hasil data processing. Dengan kata lain, berdasarkan hasil pengolahan dan tafsiran atau informasi yang ada, pernyataan atau hipotesis yang telah dirumuskan terdahulu, kemudian dicek, apakah terjawab atau tidak atau apakah terbukti atau tidak.

f. Generalization (menarik kesimpulan atau generalisasi)

Tahap generalisasi atau menarik kesimpulan adalah proses menarik sebuah kesimpulan yang dapat dijadikan prinsip umum dan berlaku untuk semua kejadian atau masalah yang sama, dengan memperhatikan hasil verifikasi. Berdasarkan hasil verifikasi maka dirumuskan prinsip-prinsip yang mendasari generalisasi. Setelah menarik kesimpulan, siswa harus memperhatikan proses generalisasi yang menekankan pentingnya pe nguasaan pelajaran atas makna dan kaidah atau prinsip-prinsip yang luas yang mendasari pengalaman seseorang, serta pentingnya proses pengaturan dan generalisasi dari pengalaman-pengalaman itu.

\section{Jurnal Refleksi Edukatika}


Discovery learning berbasis scientific approach merupakan pembelajaran dalam kelompok kecil yang membimbing siswa untuk menemukan suatu konsep dengan menggunakan pendekatan ilmiah, melalui beberapa tahapan, yaitu: (1) Stimulasi atau pemberian rangsangan; (2) Identifikasi atau pernyataan masalah; (3) Pengumpulan data; (4) Pengolahan data; (5) Pembuktian; dan (6) Generalisasi atau menarik kesimpulan. Menurut Permendikbud no. 81 A Tahun 2013 lampiran IV tentang Pedoman Umum Pembelajaran dinyatakan bahwa proses pembelajaran menggunakan pendekatan ilmiah terdiri atas lima pengalaman belajar pokok yaitu:

a. Mengamati

Kegiatan belajar yang dapat dilakukan yaitu membaca, mendengar, menyimak, melihat (tanpa atau dengan alat).

b. Menanya;

Kegiatan belajar yang dilakukan dapat yaitu mengajukan pertanyaan tentang informasi yang tidak dipahami dari apa yang diamati atau pertanyaan untuk mendapatkan informasi tambahan tentang apa yang diamati.

c. Mengumpulkan informasi;

Kegiatan belajar yang dilakukan dapat yaitu melakukan eksperimen, membaca sumber lain selain buku teks, mengamati objek/ kejadian/, aktivitas dan wawancara dengan narasumber.

d. Mengasosiasi;

Kegiatan belajar yang dilakukan dapat yaitu mengolah informasi yang sudah dikumpulkan baik terbatas dari hasil kegiatan mengumpulkan/eksperimen mau pun hasil dari kegiatan mengamati dan kegiatan mengumpulkan informasi.

e. Mengkomunikasikan.

Kegiatan belajar yang dilakukan dapat yaitu Menyampaikan hasil pengamatan, kesimpulan berdasarkan hasil analisis secara lisan, tertulis, atau media lainnya.

Berdasarkan uraian di atas, kemampuan berpikir matematis dapat dikembangkan melalui discovery learning berbasis scientific approach. Hal ini disebabkan pada pembelajaran tersebut terdapat lingkungan yang dapat memfasilitasi rasa ingin tahu siswa pada tahap eksplorasi. Lingkungan tersebut disebut discovery learning environment, yaitu lingkungan dimana siswa dapat melakukan kegiatan eksplorasi, penemuan-penemuan baru yang belum dikenal atau pengertian yang mirip dengan yang sudah diketahui. Lingkungan tersebut dimaksudkan agar siswa dalam proses belajar dapat berjalan dengan baik dan lebih kreatif.

Pada discovery learning berbasis scientific approach siswa dituntut untuk memiliki pemikiran-pemikiran sendiri dalam menyelesaikan tugas belajarnya. Selain itu, siswa juga diberi kebebasan untuk mengemukakan pendapat atau ide-idenya pada saat menyelesaikan suatu masalah melalui kelompok-kelompok kecil yang heterogen. Adanya kelompok-kelompok kecil tersebut mengakibatkan siswa menjadi lebih giat dan bersemangat ketika belajar. Selain itu, dengan discovery learning berbasis scientific approach, aktivitas mental siswa terfasilitasi, teroptimalkan, dan mereka dapat berperan aktif dalam menemukan konsep sendiri, serta memiliki rasa percaya yang tinggi untuk belajar matematika. Dengan demikian, pada pembelajaran tersebut, guru harus mendorong agar siswa terus berpartisipasi sepenuhnya dalam aktivitas kelompok dan bertanggung jawab terhadap pekerjaannya. Selain itu, guru memiliki tugas untuk mendorong siswa mengemukakan ide dan pendapat serta berpikir kreatif dalam memecahkan masalah yang diberikan sehingga kemampuan berpikir kreatif matematis siswa dapat berkembang secara optimal. Ketika pemikiran siswa berkembang, ia akan semakin kokoh, semakin berani mengambil risiko, sehingga memungkinkan untuk menjadi kreatif. Manusia yang kreatif adalah manusia yang berharga, terlebih dalam era teknologi sekarang ini (Mariati, 2006). 


\section{Simpulan dan Saran \\ Simpulan}

Berdasarkan kajian literatur dan pembahasan yang telah diuraikan maka diperoleh kesimpulan sebagai berikut.

a. Kemampuan berpikir kreatif matematis merupakan hal yang terpenting dalam bidang pendidikan. Dengan demikian, perlu upaya untuk mengembangkan kemampuan tersebut, diantaranya melalui discovery learning berbasis scientific approach.

b. Kemampuan berpikir kreatif matematis perlu dipupuk dan dikembangkan untuk memungkinkan anak mewujudkan potensinya secara optimal. Beberapa cara guru untuk mengembangkan kemampuan tersebut yaitu memberikan peluang bagi anak untuk mengungkapkan pikiran dan perasaannya (discovery).

\section{Saran}

Karena kemampuan berpikir kreatif matematis sangat diperlukan dalam mata pelajaran matematika, disarankan agar guru melakukan perbaikan dan peningkatan kualitas pembelajaran, khususnya dalam membuat latihan, tugas maupun tes. Usahakan sedikit mungkin pemecahan masalah yang diberikan merupakan pemecahan yang menuntut satu jawaban yang benar. Guru sebaiknya lebih sering menggunakan pembelajaran penemuan, diantaranya yaitu discovery learning berbasis scientific approach. Akan tetapi, pembelajaran tersebut pada dasarnya membutuhkan waktu yang cukup banyak sehingga perlu manajemen waktu yang baik. Hal ini dikarenakan dalam proses pembelajarannya, siswa dituntut untuk menyelesaikan masalah tanpa terlebih dahulu diberikan konsepnya. Bagi siswa yang terbiasa dengan pembelajaran ekspositori, hal ini akan membutuhkan penyesuaian waktu dan kadang membutuhkan usaha ekstra dari guru dalam mendorong siswa agar terlibat aktif dalam proses pembelajaran.

\section{DAFTAR PUSTAKA}

Arends, R. I. (2008). Learning to Teach (belajar untuk mengajar). Yogyakarta: Pustaka Belajar.

Herdian. (2010). Metode Pembelajaran Discovery (Penemuan). [Online]. Tersedia di https://herdy07.wordpress.com/2010/05/ 27/metode-pembelajaran-discoverypenemuan/. Diakses 19 Desember 2015.

Huda, U. (2014). Peningkatan Kemampuan Berpikir Kreatif Matematis dan Habits of Thinking Independently (HTI) Siswa melalui Pendekatan Open-Ended dengan Setting Kooperatif. Tesis, Sekolah Pascasarjana, Universitas Pendidikan Indonesia.

Kemendikbud. (2014). Materi Pelatihan Guru Implementasi Kurikulum 2013 Tahun Ajaran 2013/2014. Jakarta: Badan Pengembangan Sumber Daya Manusia Pendidikan dan Kebudayaan dan Penjamin Mutu Pendidikan.

LTSIN. (2004). Learning Thinking. Scotland: Learning and teaching Scotland.

Mahmud. (2010). Psikologi Pendidikan. Bandung: Pustaka Setia.

Mariati. (2006). Pengembangan Kreativitas Siswa Melalui Pertanyaan Divergen pada Mata Pelajaran Ilmu Pengetahuan Alam (IPA). [Online]. Tersedia di http://jurnal.pdii.lipi.go.id/admin/jurnal/ 126306759773.pdf. Diakses 10 Oktober 2015.

Munandar, S. C. U. (1999). Pengembangan Kreativitas Anak Berbakat. Jakarta: PT Rineka Cipta.

Mustafa, A. N. (2014). Upaya Meningkatkan Kemampuan Berpikir Kritis dan Kreatif 
serta Self-Efficacy dalam Pembelajaran Matematika melalui Discovery Learning. Tesis, Sekolah Pascasarjana, Universitas Pendidikan Indonesia.

Purwaningrum, J. P. (2012). Penerapan Model Wallas untuk Mengidentifikasi Proses Berpikir Kreatif dalam Pengajuan Masalah Matematika Peserta Didik Kelas XI IPA Materi Pokok Fungsi Komposisi. Prosiding Seminar Nasional Matematika VI. Jurusan Pendidikan Matematika, FMIPA UNNES, hlm. 233240.

Risnanosanti. (2009). Penggunaan Pembelajaran Inkuiri dalam Mengembangkan Kemampuan Berpikir Kreatif Siswa SMA di Kota Bengkulu. Prosiding Seminar Nasional Matematika dan Pendidikan Matematika. Jurusan Pendidikan Matematika, FMIPA UNY, hlm. 441-452.

Siswono, T. Y. E.(2007). Penjenjangan Kemampuan Berpikir Kreatif dan Identifikasi Tahap Berpikir Kreatif Siswa dan Memecahkan dan Mengajukan Masalah Matematika. Disertasi, Sekolah Pascasarjana, Universitas Pendidikan Indonesia. (2008). Model Pembelajaran Matematika Berbasis Pengajuan dan Pemecahan Masalah untuk Meningkatkan Kemampuan Berpikir Kreatif. Surabaya: Unesa University Press

Somakim. (2010). Peningkatan Kemampuan Berpikir Kritis dan Self-Efficacy
Matematik Siswa Sekolah Menengah Pertama dengan Penggunaan Pendekatan Matematik Realistik. Disertasi, Sekolah Pascasarjana, Universitas Pendidikan Indonesia.

Sumarmo, U. (2005). Pengembangan Berpikir Matematis Tingkat Tinggi Siswa SLTP dan SMU serta Mahasiswa Strata Satu melalui Berbagai Pendekatan Pembelajaran. Lemlit UPI: Laporan Penelitian.

(2006). Pembelajaran untuk Mengembangkan Kemampuan Berpikir Matematik. Makalah disajikan pada Seminar Nasional Pendidikan Matematika dan Ilmu Pengetahuan Alam, FPMIPA UPI, Bandung

Suryadi, D. (2005). Penggunaan Pendekatan Pembelajaran Tidak Langsung serta Pendekatan Gabungan Langsung dan Tidak Langsung dalam Rangka Meningkatkan Kemampuan Matematik Tingkat Tinggi Siswa SLTP. Disertasi, Sekolah Pascasarjana, Universitas Pendidikan Indonesia.

Suryosubroto. B. (2009). Proses Belajar Mengajar di Sekolah. Rineka Cipta: Jakarta.

Usman, M. R. (2014). Meningkatkan Kemampuan Berpikir Kreatif dan Komunikasi Serta Disposisi Berpikir Kreatif Matematis Siswa SMP melalui Pembelajaran Inkuiri Model Alberta. Tesis, Sekolah Pascasarjana, Universitas Pendidikan Indonesia. 